\title{
Street food and child labor: reality on the beaches of Salvador, Bahia, Brazil
}

\author{
Comida de rua e trabalho infantil: realidade na orla marítima de \\ Salvador, Bahia, Brasil
}

\section{Permínio Oliveira Vidal Júnior ${ }^{1, *}$ \\ Ryzia de Cassia Vieira Cardoso" \\ José Ângelo Wenceslau Góes" \\ Ícaro Ribeiro Cazumbá da Silva" \\ Tássia Farias Santos Vianna" \\ Isadora Soares Paiva"}

Daniela Maria Libório Fernandes"

Hortência Fernandes Macedo"
' Universidade Federal do Recôncavo da Bahia (UFRB), Santo Antônio de Jesus, BA, Brasil

" Universidade Federal da Bahia (UFBA), Salvador, BA, Brasil

\footnotetext{
* E-mail: perminiojr@ufrb.edu.br
}

\begin{abstract}
The objective of this study was to describe the reality of children and teenagers working as street food vendors on the beaches of Salvador, and to uncover the social, economic, and sanitary aspects of their work. This cross-sectional study administered semi-structured questionnaires to 275 street food vendors under the age of 18 working on 18 city beaches. Participants' ages ranged from 5 to 17 years old, with a mean age of 13 years. Most vendors were males $(71.3 \%)$, and $94.9 \%$ attended school. The most popular foods sold were queijo coalho, acarajé, and hard-boiled quail eggs. Most vendors had poor personal hygiene, although they considered hygiene important and recognized that street foods can cause disease. Some vendors (44.7\%) cleaned the utensils daily. Few vendors (13.8\%) admitted they did not wash their hands, and the remainder claimed to wash their hands two to five times a day with water or seawater, but this practice was not observed in the field. The results of this study confirm the presence of child and adolescent labor in the street food informal labor sector and substantiates the risk of street foods to consumers' health due to vendors' ignorance of hygiene principles.
\end{abstract}

KEYWORDS: Street Food; Child Labor; Food and Nutrition Security

\section{RESUMO}

Caracterizar a realidade de trabalho de crianças e adolescentes inseridos no segmento de comida de rua, na orla marítima de Salvador, revelando o aspecto social, econômico e sanitário do trabalho desenvolvido pelos vendedores infanto-juvenis. Realizou-se estudo transversal, com aplicação de questionários semiestruturados, junto a 275 vendedores de comida de rua, menores de 18 anos, em 18 praias da cidade. Os participantes tinham entre 5 e 17 anos, média de 13 anos, eram predominantemente meninos $(71,3 \%)$ e $94,9 \%$ estudavam. Os alimentos mais vendidos compreenderam queijo coalho, acarajé e ovo de codorna cozido. A maioria dos vendedores não atendia a requisitos de higiene pessoal, embora considerassem a higiene importante e que os alimentos vendidos nas ruas poderiam veicular doenças. No que se refere à frequência de limpeza dos utensílios, $44,7 \%$ declararam lavá-los diariamente. Parte dos vendedores referiu não lavar as mãos $(13,8 \%)$, enquanto os demais disseram lavar as mãos de duas a cinco vezes por dia apenas com água ou água do mar, embora esta prática não fosse observada em campo. Os resultados confirmam a inserção da mão de obra infanto-juvenil no segmento, com oferta variada de alimentos e apontam riscos à saúde dos consumidores, devido ao desconhecimento de princípios de higiene por parte dos vendedores.

PALAVRAS-CHAVE: Comida de Rua; Trabalho de Menores; Segurança Alimentar e Nutricional 


\section{INTRODUCTION}

Street food vending has become a worldwide survival strategy for socially excluded groups because it attenuates the main structural issues affecting those living in urban areas by helping to increase employment, ensure income, reduce poverty, and improve quality of life $\mathrm{e}^{1,2,3}$.

In this setting, children preparing or selling foods on the streets of metropolitan areas represent one of the most important and noticeable groups of child workers ${ }^{4}$, despite the illegality of child and adolescent labor in many countries.

Brazil has laws, policies, and government and non-government social programs ${ }^{5}$ that establish a minimum age for employment and protect the rights of children and adolescents ${ }^{6,7}$, but children are still very vulnerable to child labor. According to the National Household Sample Survey - PNAD², Brazil had approximately 5.1 million children and adolescents aged five to seventeen years old engaging in economic activities in 2006, more than 237,000 of whom were five to nine years old.

In the country's northeast region, regional poverty forces 1.9 million children and adolescents to work $^{8}$, and most enter the labor market at a young age to increase family income. On the other hand, the market dynamics of the southeast region stimulates children and adolescents' desire to consume, encouraging them to work'.

Information on child and adolescent labor in Brazil does not describe this informal, food-related employment sector, including the work of minors participating in the production chain of street food.

In Bahia, the number of working children exceeds 500 thousand, and in the city of Salvador and its surrounding metropolitan region, approximately 55 thousand children work ${ }^{8}$. Although the participation of children in informal street food vending is historic and well known, the number of studies on the subject is inadequate ${ }^{10,11}$.

The main promoters of child employment are poverty and a market structure that facilitates the entrance of children and adolescents into the labor market ${ }^{12}$. Hence, the concurrence of poverty and the opportunity to make money selling street food in families and without participating in a formal payment system ${ }^{13}$ are associated with child labor.

From this perspective, the work performed by children and adolescents in the informal food market not only infringes upon the rights socially constituted by the Brazilian legal system and international human rights organizations ${ }^{14,15}$ but also increases the risk of unsafe street foods due to child and adolescent vendors' ignorance with regards to proper food handling and preservation techniques.

Considering the dynamic of street food trade, which employs children and adolescents, it should be noted that it is important to think about inter-sectorial articulation of health services firmly committed to promoting children's rights, actions to protect them and discussions about child labor and its impact on health.
At the same time, as suggested by Leal and Teixeira ${ }^{16}$ the sanitary surveillance needs to better understand informal food trade and street food as a complex phenomenon. In this way, the establishment of a space for reflection and discussion about food and nutritional security, food safety and work organization in a dynamic intricate environment is essential to obtain successful experiences.

Thus, the purpose of this study was to characterize the reality of the children and adolescents who sell street foods on the beaches of Salvador, Bahia, by uncovering the social, economic, and sanitary aspects of their work.

\section{METHOD}

This was a cross-sectional and exploratory quantitative study conducted from October 2008 to May 2009 on the beaches of Salvador, Bahia. This study is part of the "Street food and child labor: uncovering the reality behind the beaches of Salvador-BA and the search for food security and social inclusion" project.

Given the absence of data on child labor in the informal food market of urban areas, the sample size was calculated based on an $8.7 \%$ prevalence of child labor reported by the National Household Sample Survey ${ }^{15}$, which includes all types of child labor for children aged five to seventeen years old from the metropolitan region of Salvador. Using an error rate of $3.0 \%$ and a critical a of 0.05 , the sample should have consisted of 340 vendors. Given that the ideal sample size could not be reached, the available sample size was tested using the software Stata version 12.0 to determine its power, assuming that $50 \%$ of the entire population of working children of Salvador are street food vendors and keeping a unchanged.

Data were collected on 18 municipal beaches where various food products were sold. The vendors were recruited using itinerant sampling ${ }^{17}$. Street food vendors were defined as food vendors who worked in public places and sold ready to eat foods, that is, foods that did not require further preparation, as defined by the World Health Organization ${ }^{18}$. Participant ages were classified as recommended by the Brazilian Statute of Children and Adolescents, which defines children as individuals aged 0-11 years and adolescents as individuals aged 12-18 years ${ }^{7}$.

The municipal beaches were identified by their established borders and names. Data were collected in areas with many vendors and potential buyers.

Data collection relied on a semi-structured questionnaire previously tested in a pilot trial. The questions asked were grouped into the following categories: demographic characteristics; socioeconomic characteristics; food profile, acquisition, and storage; sanitary characteristics; and vendor's opinion. Questionnaires were filled out by supervised, trained interviewers. Visual inspection-related questions were collected through direct observation, and data-related questions were answered by interviewing the vendor. The questionnaires were administered 
after the participant's guardian signed an informed consent form (when a guardian was present) or after the minor agreed to participate in the study (when a guardian was not present).

The study followed the determinations of Resolution no. 196/96 issued by the National Health Council. It was approved by the Research Ethics Committee of the Federal University of Bahia's (UFBA) Maternity Hospital Climério de Oliveira, located in Salvador, under protocol number 14/2008, and by Salvador's Municipal Council for the Rights of Children and Adolescents (198th Regular Meeting held on June 18, 2008).

The data and variables were descriptively analyzed using the software Statistical Package for the Social Sciences (SPSS) - version 20.0. Pearson's chi-square test was used to analyze associations, and the chi-square goodness-of-fit test was used to compare proportions. Student's t-test was used to compare means of the independent groups. Probability levels were set at 0.05 for all statistical analyses.

\section{RESULTS}

Of the 307 child and adolescent vendors approached by interviewers, 275 participated in the study, resulting in a response rate of $89.6 \%$ and $79.6 \%$, respectively, of the sample needed to provide sufficient statistical power based on child labor prevalence rates in Brazil. Reasons vendors refused to participate in the study included the vendor's or guardian's fear of questioning, the failure to understand the study objectives, and the lack of time, which was often perceived as an excuse used by vendors because of their fearful facial expressions.

\section{Vendors' identification and socioeconomic characteristics}

Table shows the demographic, social, economic, and work characteristics of the child and adolescent vendors.

Most vendors were male $(p=0.000)$. Some vendors entered the labor market very early, as young as five years of age. The ages of the youngest male and female vendors did not differ. Nearly all vendors were students. All school dropouts were between the ages of 13 to 17 years old. Most participants $(63.2 \%)$ received financial aid from government social programs.

Most vendors worked on a single beach, and some worked on more than one beach or at other locations. The vendors worked many hours a day, and the mean duration of employment exceeded two years suggesting that these children and adolescents tended to remain in street food vending.

Generally, the participants worked day shifts on weekends, but a significant percentage also worked day shifts on weekdays. Most respondents were boys $(69.2 \%)$ who worked for their parents (38.5\%) or third parties $(48.7 \%)$.

The mean age of self-employed children and adolescents was higher (14.37 years) than that of children and adolescents who worked for their parents, guardians, or others. According to a complementary test that measured the association between age and work status, adolescents were usually self-employed $(p=0.000)$. This was not found to be the case for children.

The vendors had a mean gross income of $\mathrm{R} \$ 43.23 /$ day (US\$ 21.26/day) selling street food on beaches. However, adolescents made more than children $(p=0.001)$ because they usually sold more profitable foods. Nearly half of the vendors (48.9\%) shared their income with their parents, $26.6 \%$ kept all of it, $15.0 \%$ shared it with another family member, and $9.5 \%$ shared it with other third parties.

Most vendors sold street foods to increase family income (Figure 1).

Food profile, acquisition, and storage

About one-fifth $(21.1 \%)$ of the interviewees had food stalls and usually sold acarajé (a dish made from peeled beans and

Table. Demographic and socioeconomic characteristics of child and adolescent street food vendors and their work on the beaches of Salvador, Brazil. 2008-2009.

\begin{tabular}{|c|c|}
\hline Characteristics & Distribution \% (n) \\
\hline \multicolumn{2}{|l|}{ Sex } \\
\hline Male & $71.3(196)$ \\
\hline Female & $28.7(79)$ \\
\hline \multicolumn{2}{|l|}{ Age } \\
\hline Mean (amplitude) & $13.0(5-17)$ \\
\hline \multicolumn{2}{|l|}{ Attending school } \\
\hline Yes & $94.9(261)$ \\
\hline No & $5.1(14)$ \\
\hline \multicolumn{2}{|l|}{ Work location } \\
\hline Only one beach & $63.3(174)$ \\
\hline Two or more beaches & $33.1(91)$ \\
\hline Other locations & $3.6(10)$ \\
\hline \multicolumn{2}{|c|}{ Duration of employment (years) } \\
\hline Mean (amplitude) & $2.19(0.002-10)$ \\
\hline \multicolumn{2}{|l|}{ Workday (hours) } \\
\hline Mean (amplitude) & $7.14(2-13)$ \\
\hline \multicolumn{2}{|l|}{ Working days } \\
\hline Weekends & $74.9(206)$ \\
\hline Weekdays & $10.9(30)$ \\
\hline Every day & $14.2(39)$ \\
\hline \multicolumn{2}{|l|}{ Work shift } \\
\hline Morning & $5.4(15)$ \\
\hline Afternoon & $6.2(17)$ \\
\hline Day & $88.4(243)$ \\
\hline \multicolumn{2}{|l|}{ Employer } \\
\hline Self-employed & $24.7(68)$ \\
\hline Parents & $37.5(103)$ \\
\hline Third parties & $37.8(104)$ \\
\hline \multicolumn{2}{|l|}{ Gross daily income (R\$) } \\
\hline Mean (amplitude) & $43.23(5-160)$ \\
\hline
\end{tabular}




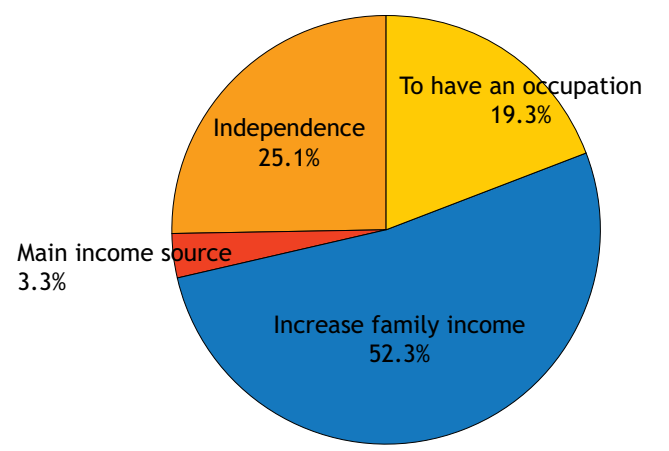

Figure 1. Provided reasons study children and adolescents sell street food on the beaches of Salvador, Brazil. 2008-2009.

deep-fried in crude palm oil). The remainder of those interviewed (78.9\%) vended foods on the beaches, walking long distances in the hot sun looking for buyers. Based on visual inspection, the items used for carrying and distributing foods were unhygienic. The vendors did not have even the most basic infrastructure or access to potable water or sanitary facilities, increasing the risk of foodborne illness.

Most foods $(77.5 \%)$ were homemade, $12.4 \%$ were commercially made, and $10.1 \%$ were unprocessed. Homemade and commercial foods included queijo coalho (a type of curd produced by fermentation and coagulation), acarajé, hard-boiled quail eggs, ice pops, ice cream, and boiled, roasted, or Japanese peanuts, among others (Figure 2).

The foods sold by the vendors were transported as follows: perishable items were carried in plastic (55.8\%) or Styrofoam (17.2\%) coolers, plastic bags (14.0\%), aluminum saucepans or baking pans $(4.7 \%)$, or other containers; non-perishable items were carried in plastic bags $(42.8 \%)$, Styrofoam coolers $(25.0 \%)$, wicker baskets $(14.3 \%)$, cardboard boxes $(7.1 \%)$, or other containers.

Regarding food processing, $23.5 \%$ of the processed foods were commercially made, and $76.5 \%$ were homemade. Homemade foods were prepared by mothers $(25.7 \%)$, other family members
(24.3\%), neighbors $(10 \%)$, storekeepers $(2.5 \%)$, or the vendors themselves (5.0\%).

\section{Sanitary characteristics}

Figure 3 shows vendor hygiene-related information. Visual inspection indicated that the vendors took very few hygienic precautions. Moreover, when vendors did take hygienic measures (especially personal) to avoid food contamination or preserve consumer health, they did so primarily to increase sales because consumers are less likely to buy from vendors with visibly poor hygiene.

Of the vendors who used utensils, $44.7 \%$ claimed to clean them once a day, $12.6 \%$ cleaned them twice a day, and $3.8 \%$ cleaned them three or more times a day. However, not one vendor was seen cleaning utensils during the interviews.

Thirty-two percent of the vendors claimed to wash their hands up to twice a day, $37.5 \%$ washed their hands from three to five times a day, and $16.7 \%$ washed their hands more than five times a day; $13.8 \%$ admitted they did not wash their hands while working on the beach. Of those who washed their hands on the beach, $83.9 \%$ used faucets available in snack shacks and $12.4 \%$ used seawater.

Based on visual inspection, $44.5 \%$ of the vendors had poor or very poor hygiene.

Vendors' opinion

Although the results show that street foods sold by children and adolescents are unhygienic, $99.3 \%$ of the vendors consider personal hygiene critical. Additionally, $69.3 \%$ of the vendors believe that street food may cause foodborne illness.

Regarding the social aspect of their work, $94.5 \%$ of the vendors said they enjoyed selling foods on the beach, and $67.2 \%$ said the work was gratifying, despite the poor work conditions. However, when asked what they would like to be doing instead of working at the time of the interview, $66.9 \%$ said they would prefer to be participating in a leisure activity.

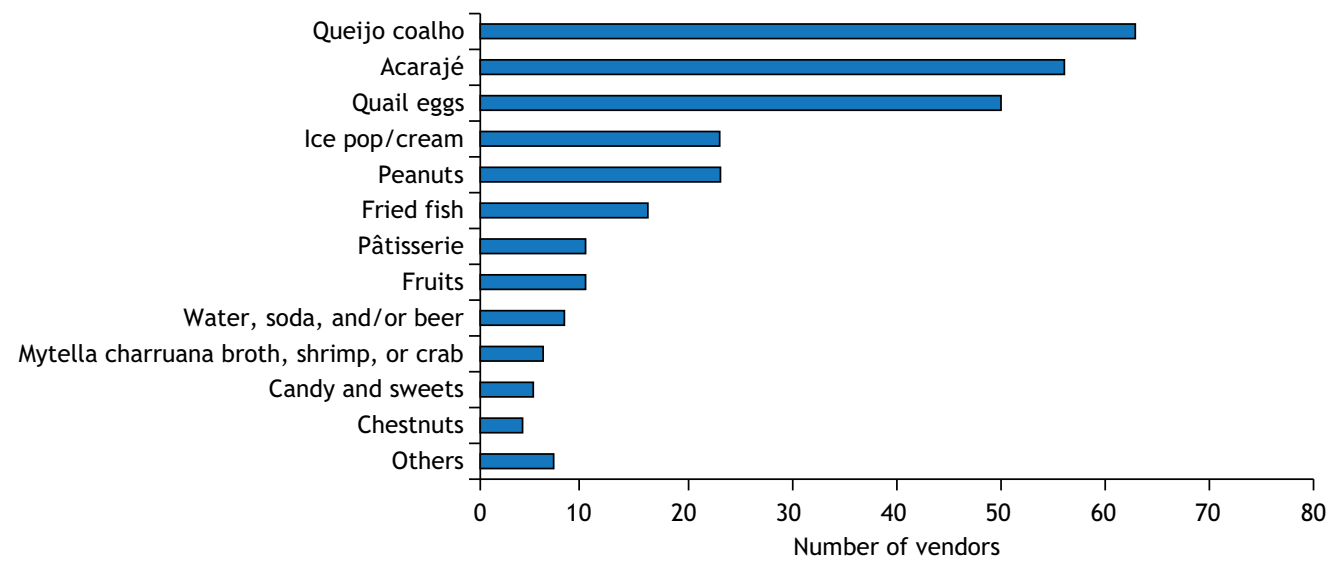

Figure 2. Foods sold by number of child and adolescent vendors on the beaches of Salvador, Brazil. 2008-2009. 


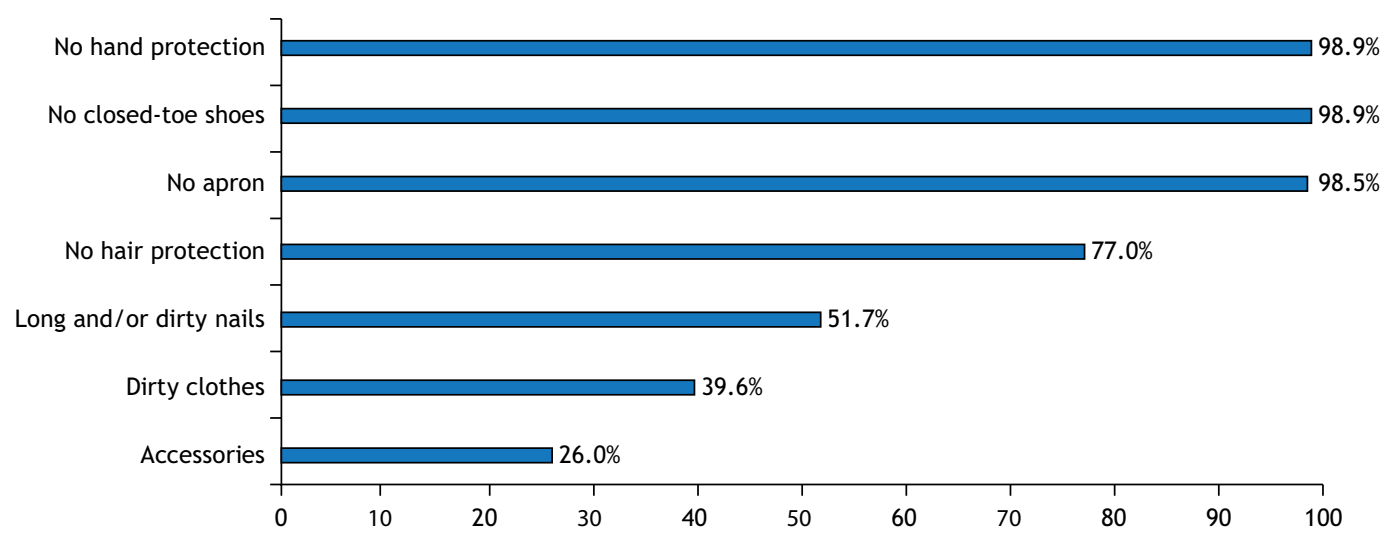

Figure 3. Personal hygiene characteristics of child and adolescent street food vendors from the beaches of Salvador, Brazil. 2008-2009.

\section{DISCUSSION}

In Salvador-BA, the interaction between street food and child labor is part of the city's everyday life. Young vendors and helpers are frequently seen working in street markets, at traffic lights, and in particular, on beaches ${ }^{10}$.

Therefore, the complexity of the street food informal labor sector, the insufficient amount of public measures for the sector, and the relationship between this sector and child labor and food safety confirm the importance of characterizing this segment from the viewpoint of child and adolescent labor.

A study on the current status of child labor in Brazil ${ }^{19}$ and another study identifying the negative and positive aspects of child labor in Peru ${ }^{20}$ also found that the majority of child laborers were males. These findings may be the result of traditional gender roles: generally girls stay at home doing chores or working in other people's homes, and boys perform other types of work outside the home ${ }^{21}$.

The very young age of some working children is confirmed by another study on child labor that found the street markets of Salvador employ children as young as five years of age ${ }^{11}$.

Food peddling is one of the main activities in urban areas, and child and adolescent peddlers are exposed to numerous risks, often performing jobs incompatible with their ages. Some physical health risks include lifting and carrying heavy objects and excessive exposure to sunlight, heat, and humidity. These activities may cause fatigue and muscle pain, among other physical health consequences ${ }^{19}$.

Most study vendors received financial aid from government social programs that require them to attend school. Although this aid may increase school attendance, it did not prevent them from working on the beach, a place not examined by social workers responsible for child and adolescent protection.

Even though most vendors work on a single beach, they work many hours a day, which not only wears them down physically and mentally ${ }^{19}$ but also compromises the quality of the foods because the foods are exposed to sunlight and/or heat for more hours than recommended ${ }^{22,23}$. Additionally, the mean duration of employment in excess of two years suggests that these vendors continue selling street food for extended periods of time.

Most workers worked day shifts on weekends because the beaches are busiest at this time, but many also worked day shifts on weekdays.

Child and adolescent street food vendors may or may not be self-employed ${ }^{13,24}$. On the beaches of Salvador-BA, some work for their immediate family, some for other employers (extended family members, stall owners, or acarajé cooks), and some are self-employed. Given that the vendors' guardians were often street food vendors and earned little income themselves ${ }^{25}$, the additional income provided by the young vendors helped to pay household bills. Most young vendors who participated in this study reported giving part or all of their income to their parents.

Thus, the acceptance of child and adolescent labor in the street food segment enables parents and guardians to increase the number of working family members, thereby increasing family income. This is especially the case among less favored social groups. However, the opportunity provided to the family by the employment of children and adolescents ${ }^{4,10}$ strongly opposes internationally established human rights ${ }^{7,26}$.

Vendors who reported working to have an occupation tended to reproduce the positive family discourse about work, that is, in addition to financial issues, working children and adolescents did not challenge the philosophic motivation associated with the positivity of working ${ }^{27,28}$.

These results are reinforced by Rizzini ${ }^{29}$ who affirms:

In this age group, individual factors, such as having their own money, being more independent, and having an occupation or skill, add to cultural factors, such as the fact that poor people's children have to work or that working teaches discipline, and to socioeconomic factors, such as the need of contributing to family income.

The unfavorable street food vending conditions witnessed by the present study are similar to those described by Omemu and Aderoju $\mathrm{u}^{30}$ in a study unveiling the practices of adult food vendors from the city of Abeokuta, Nigeria. The authors found poor storage conditions and 
vendor hygiene, confirming the existence of hygiene and food preservation problems in this segment regardless of age group.

From this perspective, the poor hygiene of child and adolescent vendors does not differ much from the poor hygiene of adult vendors, even though adults are more capable of learning correct food handling techniques ${ }^{22,30,31}$ compared to children and adolescents, who are too young to work and have limited knowledge on the requirements of safe food sales.

Based on visual inspections on the beach, the study vendors' hygiene was considered poor or very poor, a reality confirmed by other studies ${ }^{23,32,33}$ that also found poor vendor hygiene and inappropriate work conditions.

Poor transportation conditions, vendor hygiene, and long work hours directly affect the safety of the foods. In particular, long work hours lengthen the exposure of foods to unfavorable conditions, such as heat, and physical and microbial contamination. Given the diversity and nutritional composition of street foods for sale (Figure 2), homemade foods pose greater risk, although commercial foods are also dangerous under these conditions.

Because vendors share their parents' view of the dignifying nature of work, they tend to accept work as a family commitment ${ }^{20,27}$. Thus, it is possible that the acceptance and conformity seen in the study by children and adolescents was related to the fear of becoming criminals because families tend to see early employment as a means of organizing their children's time. By not letting children and adolescents loiter, parents believe they are keeping their children away from the certain social dangers.

Additionally, as described by Souza and Lage ${ }^{34}$, the conviviality of beach-goers may increase the pleasure these children experience while working, and beaches promote a more direct and intense interaction between leisure and work. Thus, these children experience pleasure while working, a condition that leads to a positive attitude towards work in food vending.

On the other hand, because the majority of vendors declared the desire to participate in leisure activities during the working period, this study both confirms and provides a contrast of the traditional perspective towards labor within this age group.

\section{CONCLUSION}

This study characterized the work reality of child and adolescent street food venders from the beaches of Salvador-BA, uncovering the social, economic, and sanitary aspects of their work. In conclusion, most vendors are males; work long hours, mainly on weekends; became street food vendors to increase family income; and sell processed foods homemade more than commercial. They do not observe proper food handling techniques, placing consumer's health at risk.

Although most vendors admitted to liking or getting satisfaction from their work, many expressed the desire to be doing something else, especially leisure activities.

The street food segment represents a challenge for sanitary surveillance, since this sector with its consumers, products, production process and work organization establishes a difficult environment to control. In face of this scenario, the realization of interdisciplinary practices could provide successful experiences of surveillance and prevention of child labor, including, but not limited to, services and health practices.

A large number of study children and adolescents began selling street food on Salvador's beaches at a young age. This not only signals child labor, which is illegal and may compromise the physical and mental development of these youth, but it also increases consumer health risks due to the vendors' ignorance of food preservation techniques and hygiene principles.

\section{REFERENCES}

1. Costarrica ML, Morón C. Estratégias para el mejoramiento de la calidade de los alimentos callejeros en América Latina y en el Caribe. Food NutrAgric. 1996;17/18:47-61.

2. Latham MC. Human nutrition in the developing world. Rome: FAO; 1997. (Food and nutrition series, vol 29). Chapter 40: Street foods.

3. Food and Agriculture Organization of the United Nations FAO. Promises and challenges of the informal food sector in developing countries. Rome: Food and Agriculture Organization of the United Nations; 2007.

4. International Labour Organization - ILO. Facts on childrem working in the streets. International Programme on the Elimination of Child Labour (IPEC). Geneva: International Labour Organization; 2003.

5. Kassouf AL, Nunes AA, Pontili RM, Rodrigues FA. Análise das políticas e programas sociais no Brasil. Brasília, DF: Organização Internacional do Trabalho; 2004.
6. Brasil. Senado Federal. Constituição da República Federativa do Brasil. Brasília, DF: Senado Federal; 1988.

7. Brasil. Lei $n^{\circ} 8.069$, de 13 julho de 1990. Dispõe sobre o Estatuto da Criança e do Adolescente e dá outras providências. Diário Oficial União. 1990 Jul 16.

8. Instituto Brasileiro de Geografia e Estatística - IBGE. Síntese de indicadores sociais 2006[cited 2007 Sep 21]. Available from: http://www.ibge.gov.br /home/\#sub_download

9. Ferro AR, Kassouf AL. Avaliação do impacto dos Programas Bolsa-Escola sobre o trabalho infantil no Brasil. Pesq Planej Econ. 2005; 35(3):417-44.

10. Góes JAW. Consumo de alimentos de rua em Salvador: o que é que a baiana (o) tem? Bahia Análise Dados. 1999;9(2):89-92.

11. Barros ES. Criança na Feira de São Joaquim: trabalho e exploração [dissertation]. Salvador : Universidade Federal da Bahia; 2008. 
12. Cervini R, Burger F. O menino trabalhador no Brasil urbano dos anos 80. In: Fausto A, Cervini R, organizers. 0 trabalho e a rua: crianças e adolescentes no Brasil urbano dos anos 80. São Paulo: Cortez; 1991.

13. Simon S. Discussion overview paper on the informal food sector. Ottawa: University of Ottawa; 2006.

14. Vieira MG. Trabalho infantil no Brasil: questões culturais e políticas públicas [dissertation]. Brasília, DF: Universidade de Brasília; 2009.

15. Instituto Brasileiro de Geografia e Estatística - IBGE. Pesquisa nacional por amostra de domicílios: síntese de indicadores sociais 2003. Rio de Janeiro: Instituto Brasileiro de Geografia e Estatística; 2004[cited 2010 Mar 24]. Available from: http://www.ibge.gov.br /home/estatistica/ sinteseindicsociais

16. Leal COBS, Teixeira CF. [Network solidarity in health surveillance: a management network for street food in Salvador, BA - Brazil]. Vigil Sanit Debate 2015;3(4):20-9. Portuguese. https://doi.org/10.3395/2317-269x.00577

17. Garin B, Aidara, A, Spiegel A, Arrive P, Bastaraud A, Cartel JL et al. Multicenter study of street foods in 13 towns on four continents by the food and environmental network of Pasteur and associated institutes. J Food Prot. 2002;65(1):146-52.

18. World Health Organization - WHO. Division of Food and Nutrition. (1996). Essential safety requirements for street-vended foods. Rev ed. Geneve: World Health Organization; 1996[cited 18 jun 2002]. Available from: http://apps.who.int/iris/bitstream/10665/63265/1/ WHO_FNU_FOS_96.7.pdf?ua $=1$

19. Carvalho IMM. $O$ trabalho infantil no Brasil contemporâneo. Cadernos CRH. 2008;21(54):551-69. https://doi.org/10.1590/S0103-49792008000300010

20. Bromley RDF, Mackie PK. Child experiences as street traders in Peru: contributing to a reappraisal for working children. Children's Geographies. 2009;7(2):141-58. https://doi.org/10.1080/14733280902798852

21. Facchini LA, Fassa AG, DallAgnol M, Maia MFS. [Child labor in Pelotas: occupational characteristics and contribution to the economy]. Ciênc Saúde Coletiva. 2003;8(4):953-61. Portuguese. https://doi.org/10.1590/S1413-81232003000400017

22. Mallon C, Bortolozo AFQ. Alimentos comercializados por ambulantes: uma questão de segurança alimentar.Publicatio UEPG/Ciênc Biol Saúde. 2004;10(3/4):65-76.
23. Rodrigues KL, Gomes JP, Conceição RCS, Brod CS, Carvalhal JB, Aleixo JAG. [Hygienic-sanitary conditios of street foods from Pelotas, RS]. Cienc Tecnol Aliment. 2003;23(3):447-52. Portuguese. https://doi.org/10.1590/S0101-20612003000300026

24. Chauliac M, Gerbouiin-rerolle P. Les enfants et l'alimentation de rue. Rome: FAO, 1996[cited 2005 Oct 29]. Available from: http://www.fao.org/docrep/W3699T/w3699t05.htm

25. Cardoso RCV, Pimentel SSP, Moreira LN, Santana CS, Cerqueira SC. Comida de rua: desvendando o mundo do trabalho e a contribuição social e econômica da atividade em Salvador-BA. Conjunt Planej. 2005;137:45-51.

26. United Nations International Children's Emergency Fund - UNICEF. Convention on the rights of the child. New York: United Nations International Children's Emergency Fund; 1990[cited 2011 Jan 11]. Available from: <http://www.unicef.org/crc/>

27. Rodrigues LD. 0 trabalho infantil na visão da escola: um estudo exploratório do tema [dissertation]. Niterói (RJ): Universidade Federal Fluminense; 2004.

28. Oliveira DC, Fisher FM, Amaral MA, Teixeira MCTV, Sá CP. [Positivity and negativity of the work in adolescents' social representations]. Psicol Reflex Crít. 2005;18(1):125-33. https://doi.org/10.1590/S0102-79722005000100017

29. Rizzini I. Pequenos trabalhadores no Brasil. In: Priore MD. História das crianças no Brasil. São Paulo: Contexto; 2002. p. 376-406.

30. Omemu AM, Aderoju ST. Food safety, knowledge and practices of street food in the city of Abeokuta. Food Control. 2008;19(4) 396-402. https://doi.org/10.1016/j.foodcont.2007.04.021

31. Nunes BN, Cruz AG, Faria JAF, Sant'ana AS, Silva R, Moura MRL. A survey on the sanitary condition of commercial foods of plant origin sold in Brazil. Food Control. 2010;21(1):50-4. https://doi.org/10.1016/j.foodcont.2009.03.016

32. Umoh VJ, Odoba MB. Safety and quality evaluation of street foods sold in Zaria, Nigeria. Food Control. 1999;10(1):9-14. https: / / doi.org/10.1016/S0956-7135(98)00149-2

33. Muinde OK, Kuria E. Hygienic and sanitary practices of vendors of street foods in Nairobi, Kenya. African J Food Agric Nutrit Devel. 2005;5(1):1-14.

34. Souza RV, Lage V. A economia da praia. Brasília,DF: Sebrae; 2008.

\section{Acknowledgments}

The authors thank the National Council for Scientific and Technological Development (Conselho Nacional de Desenvolvimento Científico $e$ Tecnológico - CNPq) for the financial support of this project. 